Discussion Paper No. 10-067

\title{
Industrial Ecology in Policy Making: What is Achievable and what is not?
}

\author{
Frank Pothen
}

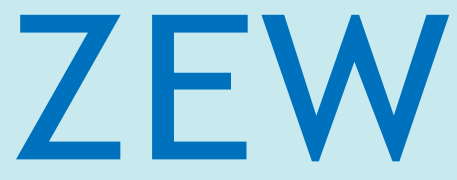

Zentrum für Europäische Wirtschaftsforschung $\mathrm{GmbH}$

Centre for European

Economic Research 
Discussion Paper No. 10-067

\title{
Industrial Ecology in Policy Making: What is Achievable and what is not?
}

\author{
Frank Pothen
}

Download this ZEW Discussion Paper from our ftp server:

ftp://ftp.zew.de/pub/zew-docs/dp/dp10067.pdf

Die Discussion Papers dienen einer möglichst schnellen Verbreitung von neueren Forschungsarbeiten des ZEW. Die Beiträge liegen in alleiniger Verantwortung der Autoren und stellen nicht notwendigerweise die Meinung des ZEW dar.

Discussion Papers are intended to make results of ZEW research promptly available to other economists in order to encourage discussion and suggestions for revisions. The authors are solely responsible for the contents which do not necessarily represent the opinion of the ZEW. 


\section{Non-technical Summary}

Industrial Ecology is a relatively new, interdisciplinary field of research, analysing the interaction between industrial activity and nature. Within this field, a multitude of instruments has been developed. Two of the most important are Life Cycle Assessment (LCA) and Material Flow Analysis (MFA).

Life Cycle Assessment records the environmental consequences caused by a product throughout its whole life cycle, from cradle to grave. Material Flow Analysis measures the input and output of materials of an economy in tonnes. Especially LCA has recently been gaining importance in European environmental policy. This development raises the question, if political measures can be developed and evaluated based on LCA and MFA. For this being the case, the instruments must be able to capture the complex consequences caused by regulatory action.

Environmental intervention triggers a multitude of effects. These include benefits and costs of measures. It has to be emphasised that in this case costs go beyond monetary costs borne by directly affected firms. Opportunity costs and costs of indirectly affected stakeholders need to be accounted for. The environmentally important rebound effect has to be covered as well. Redistributive outcomes triggered by the regulatory act are also important.

LCA and MFA as independent tools do not consider these effects adequately. LCA is able to include some of the results of environmental regulation, especially when they are directly connected to the product. Effects that only occur on the economy-wide level, however, are captured insufficiently. The MFA does measure all material flows in tonnes. The connection between weight and environmental effects remains unclear. Specific regulatory acts cannot be developed using MFA.

LCA alone as a tool to evaluate environmental policy is not sufficient. At the same time, the approach to assess the impacts of products throughout the whole life cycle appears to be promising. Therefore, a Life Cycle Based Computable General Equilibrium Model (LCBCGE) is proposed. This model represents the whole economy at industry level, while implementing the advantages of life cycle thinking. This tool could be used to evaluate political measures ex ante. 


\section{Das Wichtigste in Kürze}

Industrial Ecology ist ein relativ junges, interdisziplinäres Forschungsfeld, das die Interaktion zwischen industrieller Aktivität und der Natur untersucht. In diesem Feld sind verschiedene Instrumente entwickelt worden, zwei der wichtigsten sind die Ökobilanz (Life Cycle Assessment, LCA) und die Stoffstromanalyse (Material Flow Analysis, MFA).

Mit einer Ökobilanz werden die Umweltwirkungen eines Produktes über den ganzen Lebenszyklus hinweg erfasst, von der Wiege bis zur Bahre. Die Stoffstromanalyse misst Materialinput und -output einer Volkswirtschaft in Tonnen. Insbesondere die Ökobilanz hat in der europäischen Umweltpolitik an Bedeutung gewonnen. Diese Entwicklung wirft die Frage auf, ob auf Basis von Ökobilanz und Stoffstromanalyse Politikmaßnamen entwickelt und bewertet werden können. Damit dies der Fall ist, müssten die Instrumente die komplexen Konsequenzen von Regulierungsmaßnahmen erfassen können.

Umweltpolitische Eingriffe lösen eine Vielzahl von Effekten aus. Dazu gehören Nutzen und Kosten der Maßnahmen. Es ist zu beachten, dass die Kosten über die monetären Kosten der betroffenen Unternehmen hinausgehen. Auch Opportunitätskosten, sowie die Kosten indirekt betroffener Akteure müssen in die Betrachtung mit einbezogen werden. Weiterhin ist der ökologisch bedeutsame Rebound-Effekt zu berücksichtigen. Auch Umverteilungswirkungen, die durch Eingriffe in die Märkte ausgelöst werden, sind von Bedeutung.

Sowohl Ökobilanz als auch Stoffstromanalyse können diese Effekte als eigenständiges Werkzeug nicht ausreichend erfassen. Die Ökobilanz kann die Wirkungen von Umweltregulierung zum Teil mit einbeziehen. Das gilt vor allem für Wirkungen, die einem Produkt direkt zurechenbar sind. Wirkungen, die erst auf gesamtwirtschaftlicher Ebene sichtbar werden, können jedoch nur unzureichend berücksichtigt werden. Die Stoffstromanalyse misst alle Materialbewegungen in Tonnen. Der Zusammenhang zwischen Gewicht und ökologischen Wirkungen erscheint allerdings unklar. Konkrete politische Maßnahmen können auf Grundlage von Stoffstromanalysen nicht entwickelt werden.

Die Ökobilanz ist als Werkzeug zur Beurteilung von Regulierungsmaßnahmen nicht ausreichend. Gleichzeitig erscheint der Ansatz vielversprechend, durch Produkte verursachte Umweltprobleme über den ganzen Lebenszyklus hinweg zu untersuchen. Daher wird in dieser Arbeit ein lebenszyklusbasiertes berechenbares allgemeines Gleichgewichtsmodell (Life Cycle Based Computable General Equilibrium Model, LCB-CGE) vorgeschlagen. Das Modell soll die gesamte Volkswirtschaft auf sektoraler Ebene abbilden und gleichzeitig die Vorteile des Lebenszyklus-Gedankens besitzen. Mit dem Modell wäre es möglich, politische Maßnahmen ex ante zu beurteilen. 


\title{
Industrial Ecology in Policy Making: \\ What is Achievable and what is not?
}

\author{
Frank Pothen \\ (ZEW Mannheim)
}

\begin{abstract}
A diverse set of tools has been developed in Industrial Ecology to tackle the problems caused by human economic activity. These instruments include Life Cycle Assessment (LCA) and Material Flow Analysis (MFA). Especially LCA is now increasingly used in policy making. Design and Evaluation of policy measures necessitates careful weighing of costs and benefits. One has to consider the complex economic effects imposed by regulation, like costs for the industries affected by regulation, indirect effects on other industries and ecologically important rebound effects. This article discusses to what extent this evaluation is possible within LCA and MFA models. It is found that these models do not sufficiently incorporate the overall consequences of regulation and hence are not very suitable to measure the advantages or disadvantages of regulations. Therefore, adding economic aspects to Industrial Ecology models seems promising. In policy making, the effects imposed on the whole economy have to be captured, which calls for a general equilibrium framework. A Life Cycle based Computable General Equilibrium Model is proposed as a tool to assess the economic effects of regulation while remaining in life cycle thinking.
\end{abstract}

Keywords: industrial ecology, life cycle assessment, material flow analysis, environmental regulation, partial equilibrium modelling, computable general equilibrium modelling

JEL: D58, Q50, Q57, Q58

Acknowledgments: I would like to thank Klaus Rennings and Simon Koesler for their critique of earlier versions of this paper. I am also grateful for the valuable comments by Andreas Löschel, Gjalt Huppes and Roland Clift, as well as the participants of the $3^{\text {rd }}$ EcoEfficiency Conference in Egmond aan Zee.

Correspondence: Frank Pothen, Centre for European Economic Research (ZEW), Mannheim, P.O. Box 1034 43, 68034 Mannheim, Germany, pothen@zew.de 


\section{Introduction}

Even though Industrial Ecology is a relatively young field of research, it has developed a diverse set of tools, including Life Cycle Assessment (LCA) and Material Flow Analysis (MFA). These tools encounter rising interest from policy makers, a fact that especially holds true for Life Cycle Assessment, which is increasingly used in product based regulation. A notable example is the EU Commission's communication on the Integrated Product Policy, which states that "LCAs provide the best framework for assessing the potential environmental impacts of products currently available” (European Commission, 2003). Another example of European legislation is the Energy-Using Products Directive (European Commission, 2005). ${ }^{1}$ Indeed, Industrial Ecology tools are now used to make the step from "what" to "how" (Andrews, 2000).

Regulation always implies an intervention in market mechanisms. This induces a variety of effects. Some people benefit from a regulatory act, others have to bear its costs. In environmental regulation, rebound effects can occur dampening the effectiveness of an instrument. The new rules may also have redistributive consequences. Sound policy making has to keep these effects in mind and a careful weighing of costs and benefits is necessary. It is important to take an economy-wide perspective for this task. To model and to analyse the complex mechanisms lying beneath such effects are the realm of economics.

It is challenging to bridge the gap between both worlds. That is, to combine Industrial Ecology's holistic perspective on environmental problems with Economics’ knowledge about market mechanisms. This paper seeks to contribute to this task by answering three questions: Are LCA and MFA appropriate tools for policy making? Which economic model is advisable for policy evaluation for which regulation to be assessed? How could a combination between quantitative economic models in particular Computable General Equilibrium Models and LCA look like?

The paper is organised as follows: In chapter 2 we describe and discuss two of the major instruments in Industrial Ecology, Life Cycle Assessment (LCA) and Material Flow Analysis (MFA). In chapter 3 we explain important effects of environmental regulation that need to be taken into consideration in thorough policy making. Building upon this, Chapter 4 analyses if LCA and MFA can be used as independent tools in policy making. Furthermore, approaches

\footnotetext{
${ }^{1}$ More examples can be found in Rebitzer et al. (2004).
} 
to combine Life Cycle Assessment with economic modelling are discussed. Chapter 5 concludes.

\section{Industrial Ecology and its Tools}

\subsection{Foundations of Industrial Ecology}

Industrial Ecology is a relatively new field of research. The article "Strategies for Manufacturing” by Frosch and Gallopoulos (1989) is commonly seen as its initial point, though similar concepts appeared before (for an overview see Erkman, 1997). Industrial Ecology is concerned with industry, thus with products and their manufacturing processes. Furthermore, human industrial activity as a whole are perceived similar to a biological system that is embedded within nature (Lifset and Graedel, 2002). The perception of human industrial activity similar to biological systems has been coined "biological analogy" (Allenby and Cooper, 1994).

There are two main biological analogies. The first one is the industrial ecosystem analogy. Firms, households, and other economic subjects together form an ecosystem, which is embedded within the bigger ecosystem of nature. Both systems are linked in various ways (Frosch and Gallopoulos, 1989). The second analogy is the industrial metabolism analogy. There, human activity as a whole is perceived like an organism. Similar to its biological counterpart, the industrial metabolism ingests raw materials and excrements wastes (Ayres, 1994). ${ }^{2}$

Although being a young field, Industrial Ecology has developed a diverse set of tools. This paper focuses on two of the most important instruments, Life Cycle Assessment (LCA) and Material Flow Analysis (MFA). Life Cycle Assessment essentially identifies the environmental effects caused by a product over its whole life cycle. It is an instrument at micro level, analysing the basic cause of environmental impacts, the product. MFA on the other hand is a macro level tool that quantifies physical inputs and outputs of an economy at a highly aggregated level. These instruments are discussed in a somewhat general manner. This leads to a danger of omitting other instruments or developments within the LCA and MFA methodology, which may offset some of the critique. But we take this risk in order to keep our arguments general enough to be applicable in the whole realm of Industrial Ecology.

\footnotetext{
${ }^{2}$ For an historical overview over the industrial (or, more broadly, society’s) metabolism analogy see FischerKowalski (1998).
} 


\subsection{Life Cycle Assessment}

The general idea of Life Cycle Assessment is to record all environmental impacts caused by a product during its whole life cycle, from the extraction of raw materials, to the production, the use phase and the disposal (cradle-to-grave approach). A Life Cycle Assessment consists of four steps, defined in the ISO 14040 series. The first step is the goal and scope definition. At this point, the exact target of the LCA, the coverage of the study and the functional unit are defined. The functional unit is the subject of the analysis. It does in general not correspond to a product, but the service provided by this product. The functional unit is not "a light bulb”, but "five hours of lighting per day with certain brightness". One has to bear this in mind, even though LCA is commonly referred to as a concept to assess the environmental impacts of products. The second step is the Life Cycle Inventory Analysis in which the life cycle of the product is modelled and the associated emissions and resources needed are recorded. In the third step, the Life Cycle Impact Assessment, this information is composed into impact categories such as climate change, acidification or human toxicity. These categories can be normalised against reference values, grouped into other categories or weighted by several methods. An LCA ends with an interpretational step. Assumptions and results are discussed in this step. ${ }^{3}$ The steps are pictured in Figure (1).

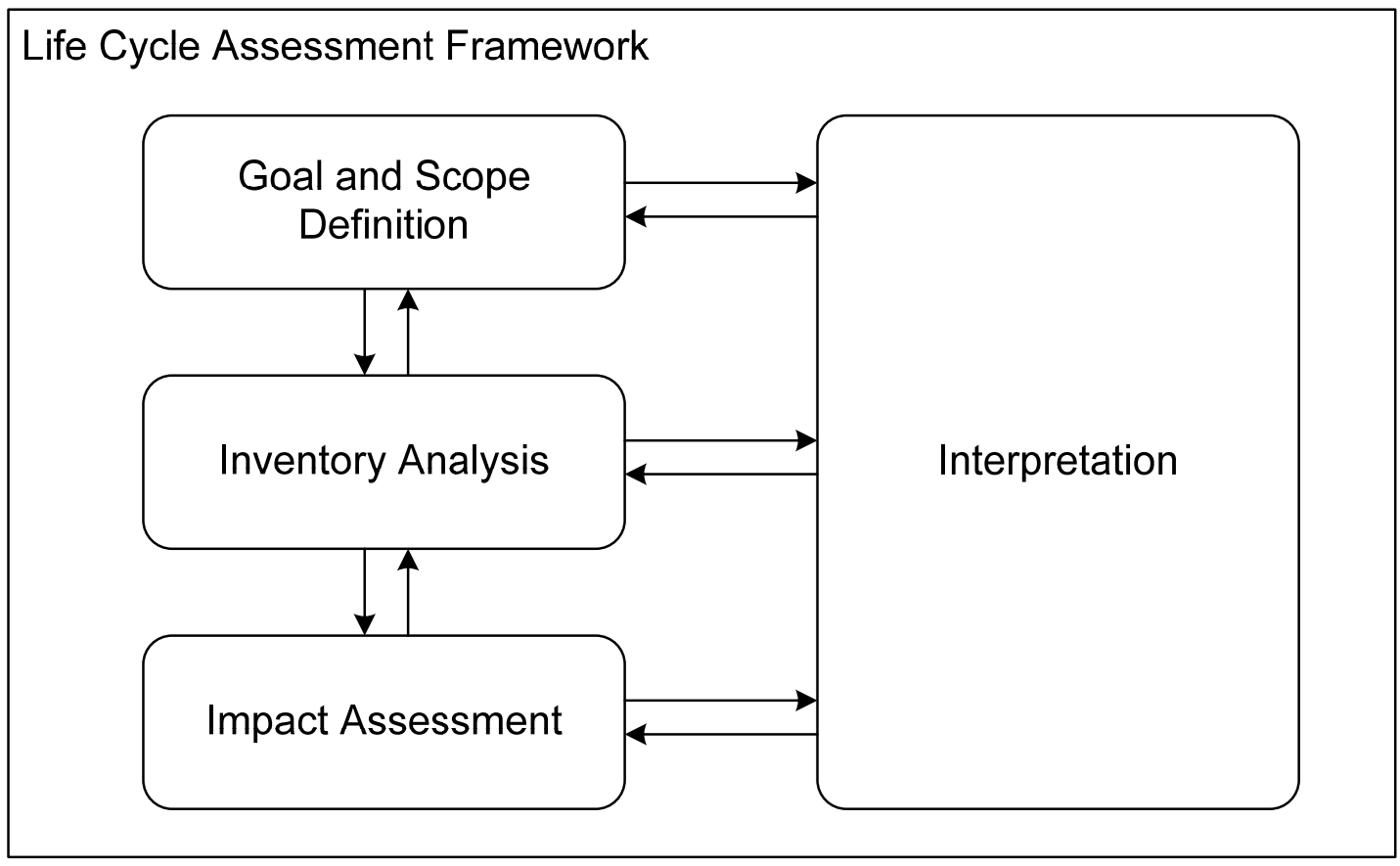

Fig. 1: The four steps of a Life Cycle Assessment (based on Guinée, 2002).

\footnotetext{
${ }^{3}$ A more detailed description can be found in Rebitzer, et al. (2004) and Pennington et al. (2004). A methodological guide for the conduction of an LCA can be found in Guinée (2002).
} 
It is commonly said that the first Life Cycle Assessment was conducted for Coca-Cola to compare the environmental effects of different soft drink containers (Hunt and Franklin, 1996). The LCA approach has been evolved in several directions, see e.g. Udo de Haes et al. (2004) and Finnveden et al. (2009) who summarise recent developments. One can also see the emergence of broader life cycle thinking that goes beyond the limitations of a single analytical tool (Heiskanen, 2002).

LCAs are used to analyse the impact of a vast variety of products, ranging from food and beverages (Andersson et al., 1998; Cordella et al., 2008) to solar cells (Stoppato, 2008), from paper production (Lopes et al., 2003) to military equipment (Hochschorner et al., 2006). The comparison between organic and conventional milk production in Sweden, conducted by Cederberg and Mattsson (2000), will here serve as an example for a Life Cycle Assessment. The functional unit in their LCA is $1000 \mathrm{~kg}$ of milk, corrected for fat and protein content. Data is to a large extent provided by two dairy farms in the West of Sweden. The life cycle inventory includes the production of milk on the farm, the cultivation of fodder (including necessary fertilisers and pesticides) and transports. Buildings are excluded, because their design is very similar for both organic and conventional production. Machinery is also excluded due to data uncertainties. Main differences in the life cycle of conventional and organic milk result from differences in the fodder used. Organic farms are obligated to produce half of their feed themselves, and their use of conventionally produced feed is limited to $5 \%$ of all feed. The LCA shows that organic farming is the preferable form an environmental point of view, for most of the impact categories. A drawback is the significantly higher land use of organic feed production.

Life Cycle Assessment yields a holistic image of environmental consequences connected with products. In this context holistic means that not only production is covered, but also use and disposal which significantly influence the environmental impacts of many products. An LCA can be carried out on a very detailed level, and it can be used in a comparative manner. By modelling hypothetical production processes or inputs, LCA can also guide the development of ecologically sound products. The holistic perspective avoids shifting problems between the phases of the life cycle.

Life Cycle Assessment underlies several limitations. Firstly, the impacts calculated within the impact assessment phase are neither specific to regions, nor to time periods (Udo de Haes, et al., 2004). Therefore, potential environmental impacts rather than actual impacts are calculated. Secondly, LCA calculates environmental impacts per unit of the product. This 
implies that the impact rises linearly with the amount of product manufactured. Such a calculation ignores for example, that many harmful substances have limits that, if exceeded, make them dangerous, which is a nonlinear effect (Owens, 1997). Thirdly, a complete cradleto-grave analysis is usually not feasible for complex products, which are sometimes composed of thousands of parts. This raises the problem of setting the system boundaries appropriately (Suh et al., 2004). Fourthly, a thorough LCA is expensive and time consuming. The fifth point to mention here is the implicit assumption about the production function set during the inventory analysis. They are usually assumed to be of Leontief type, meaning that no substitution between inputs is possible. A change of inputs or production technology, for example due to regulatory action, is not explained endogenously within the model, but has to be implemented by the researcher.

The standard process based LCA models the production process of a product to collect the corresponding environmentally relevant emissions. Alternatively, one can collect environmentally relevant emissions using economy-wide input-output tables. Input-Output modelling was developed by Leontief (1936). The idea is as follows (for a more detailed discussion see Miller and Blair, 2009). The whole economy is described by the system of linear equations

$$
x-A x=f
$$

where $f$ denotes the vector of final consumption, $x$ the vector of production of all industries in the economy and $A$ the matrix of technical coefficients. Each element $a_{i j}$ in matrix $A$ shows, how much input from industry $i$ is necessary for the production of industry $j$. Two things are important to note here. First, everything is measured in monetary terms, so the matrices do not show physical production and consumption, but purchases and sales. Second, the tables are based on industries here. Even though is possible to construct input-output tables on a product-by-product base, it is usually done on an industry-by-industry base. Factoring out $x$ and premultiplying with $(I-A)^{-1}$ yields:

$$
x=(I-A)^{-1} f
$$

The term $(I-A)^{-1}$ is known as the Leontief-Inverse. Each of its elements $l_{i j}$ indicates how far the production of $i$ rises, if the final demand in industry $j$ rises by one unit. The InputOutput Approach can be extended to incorporate environmental impacts (Leontief, 1970). Let 
$R=\left[r_{j k}\right]$ denote the matrix of pollution output, where each element indicates the physical amount of emission of pollutant $k$ associated with one monetary unit of production in industry $j$. Multiplying this matrix with (2) yields the vector $e$ of environmental impacts of the economy

$$
e=R x=R(I-A)^{-1} f \text {. }
$$

Matrix $R(I-A)^{-1}$ shows the total environmental impacts induced by one unit of final demand (Miller and Blair, 2009). This framework is used to compute total emissions in an Economic Input-Output LCA (EIO-LCA), see e.g. Lave et al. (1995) and Hendrickson et al. (1998).

By avoiding the challenge to model the whole production process by hand, an EIO-LCA can be conducted much quicker and at lower costs than a process based LCA. It also comprises the whole economy in its input-output tables and therefore boundary setting is unnecessary. The drawbacks of EIO-LCA include the problem of linking monetary information in IO tables to physical environmental values and the high level of aggregation within the data (Hendrickson et al., 2006). A disaggregation of input-output matrices may sometimes be necessary. Approaches to this are proposed by Joshi (1999). Also, the use phase and the disposal are not connected to the corresponding products in the IO tables, which is necessary to perform a cradle-to-grave analysis. An introduction of the use and disposal phase is possible, but necessitates additional effort (Heijungs et al., 2006).

\subsection{Material Flow Analysis}

Another important element of the Industrial Ecology toolbox is the Material Flow Analysis (MFA). This tool is rooted in the industrial metabolism analogy. Human economic activity is perceived as an organism, which ingests raw materials and egests wastes and emissions. The general idea of MFA and other related instruments is to measure the size of the industrial metabolism (Daniels and Moore, 2001). ${ }^{4}$

Generally speaking, MFA calculates the size of the industrial metabolism in tonnes. The methodology is described in detail in Eurostat (2001). It accounts for the inputs and the outputs of the economy, as well for the stock of materials. The stock includes building, infrastructure, machinery and durable consumer goods. The flows include materials that are processed into products and the corresponding emissions as well as material that accrues in

\footnotetext{
${ }^{4}$ Daniels and Moore (2001) and Daniels (2002) review some of these instruments.
} 
fabrication but is not used as an input to the economy. This material is often called hidden flow. Seminal MFAs have been conducted by Adriaanse et al. (1997) and Matthews et al. (2000) for the World Resource Institute. For an overview over the development of MFA see Fischer-Kowalski and Hüttler (1998).

After quantifying inputs, outputs and the physical stock, one can compile a set of indicators that describe the size of the industrial metabolism (for an overview see Eurostat, 2001; for further discussion Bringezu et al., 2003). Two well known indicators are the Direct Material Input (DMI) and the Total Material Requirement (TMR). The DMI measures all materials that are processed into products, either domestically or as imports. The TMR includes all materials in the DMI, plus the domestic and foreign hidden flows. The indicators can be compared with macroeconomic indicators, such as the GDP.

Material Flow Analysis can be used to draw a quantitative picture of the industrial metabolism. It shows the connection between inputs and outputs. The physical growth of the economy is made visible. When compared with economic indicators, derived indicators can illustrate the connection between economic and physical growth (see e.g. Bringezu et al., 2004).

MFA underlies several severe limitations. It aggregates all flows based on their weight, first into input, output and stock categories, later into scalar indicators. When one wants to tackle environmental problems using the gathered information, it is necessary to (at least implicitly) assume that moved masses are correlated with environmental problems. This assumption is highly questionable (see e.g. Cleveland and Ruth, 1998). One may use derived indicators as a proxy for yet unknown environmental impacts, in the sense of the precautionary principle. Again, it is doubtable that indicators that are dominated by big masses which are moved in and out of the economy reflect future problems very well. Another problem is that the economy itself is treated as a black box. While recording the inputs, outputs and stocks, material flows within the metabolism are neglected in the economy-wide MFA. To get deeper insights into the flow of materials within an economy necessitates modelling them explicitly, for example with physical-input output tables (Giljum and Hubacek, 2009). 


\section{Economic Assessment of Environmental Policy}

\subsection{Benefits of Environmental Regulation}

From an economist's point of view, environmental problems are cases of external effects. The economic activities of one party have consequences on utility or production of another: polluted water can cause crop failure; polluted air can cause health damages. The underlying problem is, that these consequences are not compensated through market transactions, because property rights are set insufficiently (Coase, 1960). The results are too large quantities of pollution, causing welfare losses to society. The goal of environmental policy is to correct these market failures by internalising external costs and thus improve the welfare of society.

The valuation of environmental impacts, in monetary or other terms, is a complicated and controversial task. It may even be considered impossible, because it assumes that different environmental problems can be offset against each other (for a discussion see Finnveden, 1997). Despite these fundamental questions, valuation always takes place in environmental policy. This may happen explicitly (e.g. by valuation in monetary units) or implicitly (e.g. by deciding whether an environmental policy measure is undertaken or not). Policy makers operate in a world with scarce resources; each Euro or Dollar in the government budget can only be spent once. Hence, when policy makers decide to implement e.g. greenhouse gas abatement measures, they implicitly value climate change more important than other problems. To evaluate environmental problems in monetary terms makes the decision process more transparent and benefits comparable to costs.

A large body of literature exists about methods to measure the value of environment in economics. An overview can be found in Friedman (2003) and in Haab and McConnell (2002), who focus more on empirical aspects. The general idea of the economic methods is the following: environmental quality yields utility to people. Furthermore, it is assumed, that this utility can be substituted by utility from the consumption of other goods. Yet, there are no markets for environmental quality. Therefore, it is necessary to use non-market valuation methods to determine how much money people are willing to pay for environmental quality, or how much money people would accept to waive for environmental quality. The most prominent approaches to this are stated preference and revealed preference approaches (Haab and McConnell, 2002). Stated preference methods ask directly for the willingness to pay or to accept, while revealed preference methods take a reading from actual behaviour. 
Environmental quality can also serve as an input to production, water and soil quality for example is essential to agriculture. When regulation raises the quality of inputs, additional benefits arise that should be accounted for.

LCA includes an optional step of weighting or valuation (Guinée, 2002). As the name suggests, weights are assigned to impact categories reflecting their importance. Weighted categories themselves can be aggregated into a scalar indicator of environmental impact. There are several methods to value environmental impacts in the LCA framework (see e.g. Hertwich et al., 1997; Notarnicola et al., 1998; Finnveden, 1999). These include approaches expressing environmental impacts in monetary terms derived from economic methodology. Therefore, it is generally possible to quantify the benefits from environmental regulation within the LCA framework.

\subsection{Costs of regulation}

\subsubsection{Direct Costs of Regulation}

From an economic point of view, environmental regulation introduces new incentives to change the behaviour of firms or individuals. These incentives can be implemented by command-and-control regulation, or they can be established by changing prices in economic regulation. But adaptation to new incentives is a costly task. It is important to note that the term costs in economics goes beyond monetary values. Whenever scarce resources are used due to environmental regulation, other beneficial activities can not be performed. These opportunity costs have to be considered as well. An overview over the costs associated with environmental regulation can be found in Jaffe et al. (1995) and Pizer and Kopp (2005). In this section the most obvious type of costs will be described. Those stem directly from the adaptation to environmental laws, i.e. direct costs of regulation.

When firms are affected by regulation, they react in several ways to comply with the rules. In some situations, a substitution of a "dirty" by a "clean" input is the best way to comply. An example is fuel switching from coal to natural gas in electricity generation after the implementation of a $\mathrm{CO}_{2}$ emission trading scheme. In other cases, the law leads to changes in production processes. The installation of scrubbers for fuel-gas desulphurisation may serve as an example here. In some cases it is required to redesign products to comply with the regulation. For example, the limitations in the use of tetraethyl lead in gasoline beginning in the 1970s necessitated engines that work with unleaded gasoline. 
Market based regulation provides the opportunity to avoid these compliance measures, at least to some degree, by paying taxes, fees, etc. instead. This mechanism generally ensures that compliance is performed where it is least costly, minimising the costs of compliance on an economy-wide level.

One also has to comprise transaction costs associated with the regulation. Firms need to be informed about current regulations to do their paperwork, to buy and sell emission rights in trading systems, and so on. These are also compliance costs of regulation, despite the fact that they are hard to measure. But irrespective of the concrete method they choose, adaption to the new rules generally imposes additional costs on firms.

Consumer based regulation works similarly. Command-and-control regulation forces people to change their behaviour and by that incurs a loss of utility. A notable example is the ban on incandescent light bulbs in several countries worldwide. Even though compact fluorescent lamps save energy as well as money over their lifetime, time discounting makes incandescent light bulbs with their low purchase costs preferable to consumers (Kooreman, 1996). Prohibiting their sale implies a loss of utility to consumers. Economic regulation leaves a choice to alternatively pay taxes or fees that punish environmentally undesirable behaviour. Money spent this way can not be used to consume other goods, also leading to a loss of utility.

Changes in inputs, production processes or product characteristics can be modelled well in an LCA as it is a product based instrument. The same holds true for consumer based regulation, if it results in changed patterns of usage. The costs of such changes are, however, not addressed. But when modelling an economic life cycle together with an ecologic one, direct costs can be captured. The approach that calculates costs of a product over its whole life cycle is known as Life Cycle Costing (LCC). Its usefulness has been highlighted by Norris (2001a; 2001b).

\subsubsection{Partial Equilibrium Costs}

As discussed before, firms can take several actions to comply with environmental regulation. They can substitute inputs, change the production process or redesign products. All these measures induce second round effects for the sector affected by regulatory action. Consider

\footnotetext{
${ }^{5}$ The details of Life Cycle Costing and its methodology are not within the scope of this paper. For an overview see Hunkeler et al. (2008). Applications can be found for example in Schwab Castella et al. (2009) and Vercalsteren et al. (2010).
} 
the fuel switch mentioned before. When firms are forced to change their inputs towards natural gas, this leads to an increasing demand for gas. The increased demand will lead to an increase of the price for gas. The magnitude of the price rise is determined by the elasticity of supply. When gas suppliers are close to their capacity constraints, the price increase can become significant.

Firms may also need to change the production technology or their products to comply with environmental rules. Besides financial expenditures on e.g. new machinery, and rising prices of investment goods due to rising demand for machinery, there are opportunity costs to be recognised. Whenever a company spends resources on pollution control measures, these resources can not be employed to enhance productivity or the quality of products. Hence, profits of such improvements are lost. The same holds true for innovation, where green innovation may crowd out other, possibly more profitable, innovation (Schmalensee, 1993).

For the regulated industry, costs rise through several channels, either directly or indirectly by second round effects. Higher costs lead to higher prices of the products manufactured in the regulated industry. This, in turn, reduces the demand for the product and thereby profits in the considered industry.

LCAs do not incorporate costs. But could partial equilibrium effects be captured, at least in principle, within the LCA framework? At this point, the situation is more complicated compared to direct costs. The partial equilibrium costs arise because compliance efforts alter scarcities and thereby relative prices on markets. Regarding inputs, prices to be modelled can not be represented by fixed numbers any more, but need to be expressed as functions dependent on the quantity of the input. This, however, would complicate the whole (enhanced) LCA. The LCA does analyse environmental impacts of a product measured per unit of this product. When a changing demand for the product, or more general the functional unit, shall be considered, an assessment of the overall impacts of the product has to be made. At this point, we leave the conceptual framework of Life Cycle Assessment and enter the realm of economics.

\subsubsection{General Equilibrium Costs}

Generally, industries are affected by environmental regulation to a varying extend. In particular, product based regulation is specifically determined to cover one industry: the one that manufactures the product. But usually we can not plausibly assume that the effects of the 
regulation are limited to this industry. Consider for example the case of a $\mathrm{CO}_{2}$ emissions trading system that is introduced on a market for a $\mathrm{CO}_{2}$ intensive goods. Producers that are affected will seek to minimise their compliance costs, either by reducing their emissions or by buying emission permits. Still, compliance remains costly and market prices rise. Therefore, the demand side is affected indirectly as well. The magnitude of the indirect effect is governed by the elasticities of substitution on the demand side. If the $\mathrm{CO}_{2}$ intensive good, which just became more expensive because of the emission trading system, can be replaced easily by a "green" good, mainly the polluting industry will be hit by the regulation. If the $\mathrm{CO}_{2}$ intensive product can not be exchanged easily by a "green" one, because it is too expensive, the regulation costs are actually burdened on the demand side. Similar effects appear for the inputs of the regulated industry. In an interdependent economy, this process continues through the whole economy and eventually results in a new equilibrium. These general equilibrium effects exist and they are quantitatively significant (Hazilla and Kopp, 1990).

As indicated, elasticities of substitution govern the extent to which an industry bears the costs of a policy. For policy making, it may be important how the burden of a measure is distributed between the industries. A model that encompasses the whole on an industry level is necessary to handle this task.

The aforementioned mechanism essentially distributes the costs of regulation through the economy. In a world of perfectly competitive markets the question of distribution is the only one to worry about, whereas, the problem becomes increasingly complicated in a more realistic framework. When markets are distorted, for example by taxes, the effects of environmental regulation interact with these distortions (a simple example is discussed in Pizer and Kopp, 2005). In such a case, the new intervention alters the costs of the existing one, changing the overall costs of regulation.

When assessing environmental taxes, another effect emerges that can lower the costs of the tax, the "double dividend”. The general idea is intuitive: The government levies several taxes, for example on labour or consumption. These taxes cause distortions on the markets. If we assume now that a new tax on certain pollution is raised, or alternatively an emissions trading scheme is introduced the created revenue is used to lower the rate of a distortionary tax. The first dividend stems from the fact that the tax internalises the external effect and lowers the amount of pollution. The second dividend comes from the way the revenue is used. By lowering the rate of the other tax, the distortion on the markets will be reduced. For an 
extensive discussion of the double dividend hypothesis see Goulder (1995) and the references cited within.

While the double dividend can actually lower costs of regulation, the government also has to pay other expenses in environmental policy. Environmental legislation requires, among others, work of parliaments and bureaucracy. Compliance has to be controlled by governmental agencies, courts have to resolve ambiguities and enforce laws. The extent of these costs differs significantly, depending on the respective instrument chosen.

Other, more specific consequences of environmental regulation are discussed in economic literature as well. Strict environmental regulation may for example harm the international competitiveness of an economy (Jaffe, et al., 1995). Compliance efforts may also harm the overall growth of the economy in the long run (Jorgenson and Wilcoxen, 1990). These aspects, however, are eventually part of the cost of environmental regulation.

General equilibrium effects result from the fact that a substitution between goods is generally possible and the world is essentially non-linear. To capture them, a model representing the whole economy is needed. This goes beyond the LCA framework.

\subsection{Rebound Effect}

A big share of current environmental policy deals with energy efficiency. ${ }^{6}$ The EU EnergyUsing Products Directive (European Commission, 2005) may serve as an example here. This approach is perceived as the via regia to reduce environmental impacts without endangering prosperity or competitiveness. Economic theory casts doubt on the effectiveness of such a policy. The decline in energy consumption due to an enhancement in energy efficiency may be significantly less than expected as a resulting from the rebound effect. In extreme cases, a rise in energy efficiency may even lead to an increase in energy consumption. Energy efficiency is then said to backfire. The topic was introduced to contemporary literature by Khazzoom (1980). Several aspects of the rebound effect can be distinguished, we will focus on the two most prominent ones: The direct rebound effect, which is a partial equilibrium effect and the indirect rebound effect, a general equilibrium effect. What is the economic intuition behind the rebound effect? ${ }^{7}$

\footnotetext{
${ }^{6}$ Rebound effects are usually discussed in terms of energy. But we can expect similar rebound effects when the use of other inputs, like raw materials, becomes more efficient.

${ }^{7}$ Other effects include implications for technological change and investment in a dynamic setting (Greening et al., 2000) or time use rebound effects (Jalas, 2002).
} 
First we consider the direct rebound effect. We Assume that the energy efficiency of a product, for example TV sets, increases by 10 percent. To simplify the discussion, we also assume that this increase does not raise the price of the product itself. When holding the using pattern constant, the energy consumption from watching TV decreases by 10 percent. The demand for electricity then falls and energy suppliers must lower their prices, which makes electricity cheaper. In addition to that, consumers become richer in real terms, since they buy 10 percent less electricity for watching TV at a lower price. The rebound effect stems from the reaction to this new situation. In the short run, people may spend more time watching TV. In the long run, they may buy more or bigger TV sets. Both would increase the energy consumption again, possibly leading to a decrease in the total electricity demand of less than 10 percent due to the efficiency gain of 10 percent. Empirical studies of the direct rebound mainly cover automotive transport, household heating and cooling in OECD countries. They estimate that usually between 10 and 30 percent of energy savings derived from more efficient technology are offset by the direct rebound effect (Greening, et al., 2000; Sorrell et al., 2009).

The direct rebound effect is limited to the product where the efficiency gain occurred. But for many products, it seems plausible that this effect is not of a high magnitude. Again, we consider the example of the TV set. For many people, it is probable that they will not spend more time watching TV, because time is the limiting factor for them, not the electricity bill. The size and number of TV sets is possibly constrained by their housing. Still, there is the indirect rebound effect. As mentioned before, efficiency gains make people richer in real terms and decrease electricity prices. This now may trigger an indirect rebound effect. The additional income can be spend on energy intensive goods other than TV sets, and the lower relative price of electricity sets incentives to do so. Thereby, another part of energy savings can be offset. Empirical evidence is relatively scarce for the indirect rebound effect. An overview is provided by Sorrell and Dimitropoulos (2007). But existing studies suggest that the indirect rebound effect often quantitatively exceeds the direct one. In some cases, gains in energy efficiency may indeed backfire (see e.g. Hanley et al., 2009). For example, a household that has significantly reduced the energy bill by saving electricity may spend the money for a flight to South East Asia.

When taking the rebound effect into consideration, the via regia may be a more bumpy way than assumed by many. Nevertheless, the existence of rebound effects does not generally discard energy efficiency policy, especially since backfire seems to be a rare case. But in 
policy making, possible rebounds should be taken into consideration to ensure the effectiveness of a measure.

Even though the importance of the rebound effect is widely acknowledged within the field of Industrial Ecology, the attempts to introduce it into LCA modelling remain rare. Thiesen et al. (2008) focus on a situation, where products which differ in prices are compared in a consequential LCA. They assume that the money saved by buying the cheaper good will be spend in a way that households trends towards the consumption patterns of richer households. This methodology covers an income effect, but does not account for substitution which is likely to occur when scarcities are changed by regulation.

Spielmann et al. (2008) discuss the introduction of an underground maglev train in Switzerland. They focus on time rebound effects. Therefore, they assume that the time budget devoted to travelling remains unchanged, setting the (time) income effect to zero. The substitution effects implied by the introduction of the maglev train are taken from a stated preference study.

The rebound effect arises, when microeconomic changes translate to macroeconomic changes in a non-linear manner. As a micro level tool, it is difficult to introduce these effects rigorously. To assess regulation, especially larger ones, a model that captures economy-wide phenomena is needed to account for the rebound effect appropriately.

\subsection{Distributive Effects of Environmental Regulation}

The aforementioned points are costs that appear in a standard economic cost benefit reasoning. The focus lies on the efficiency of political action. Still, in actual policy making, distributive effects play an important role. They are also relevant for the social pillar of sustainability. This eventually leads us to another relevant question: Who pays the costs of environmental protection within a society eventually?

Several surveys examine the distributional consequences of different environmental policies, including command and control measurements, tradable emission permits and in particular environmental taxes. An overview is compiled by Parry et al. (2005). Environmental regulation generally tends to be regressive. The burdens of environmental regulation are bigger for poor households, compared to their income. Still, this result is strongly dependent of the concrete implementation of an instrument. 
In the public discussion about environmental protection, employment arguments are used frequently and in an emotional way. The argument focuses on the loss of existing jobs and on the creation of new green jobs respectively, depending on the position. When trying to quantify the employment effects of pollution regulation, these sometimes seem to be even positive, yet generally small in magnitude (Morgenstern et al., 2002).

Redistributive consequences are usually not the topic of LCA. Social aspects can be covered using Social LCA (see e.g. Jørgensen et al., 2008). The issues covered in Social LCAs tend to be those that are directly connected to the production of certain goods, and the firms producing them. Redistributive effects, which can be spread throughout the whole economy, necessitate economic modelling.

\section{Shortcomings of Industrial Ecology Tools in Policy Making and Ways to Overcome Them}

\subsection{Are Industrial Ecology Tools Appropriate Tools for Policy Making?}

MFA is advocated to be introduced as an information tool for policy making (Bauer, 2009). It is based, however, on the assumption that today's, or at least tomorrows unknown, environmental problems are correlated with the weight of material flows. This assumption does not seem convincing, hence it is not possible to make statements about what is gained or lost when the derived indicators change. MFA also treats the economy itself as a black box. This implies that nothing can be said about the economic consequences of regulatory intervention. As a consequence, MFA can only be used as an instrument to measure the physical size of the economy, but not as a tool for policy making.

LCA is already used in policy making, mainly as a tool to detect products with major environmental impacts, i.e. for setting priorities in policy making. But what more is possible? LCA can provide a comprehensive and holistic overview of impacts associated with a product over its life cycle. LCA is a product based instrument and it is therefore natural to use it in product based regulation. Still, as the discussion about the rebound effect showed, an efficiency gain of $\mathrm{x}$ percent does usually not translate into a reduction of impact by $\mathrm{x}$ percent. Regulation is embedded in the economy and causes several forms of costs and benefits, as well as distributive side effects. LCA takes them insufficiently into account, but for sound policy making it is necessary to include them as well. Therefore, LCA is not appropriate as a standalone tool in this context. A combination between LCA and economic models seems 
interesting in order to overcome the problems. Several ways to construct such a combination are imaginable. Two of the most promising will be discussed below.

\subsection{Linking Life Cycle Assessment to Partial Equilibrium Models}

A Partial Equilibrium Model is an economic tool that represents a single market. It can be used to investigate the effects of regulation on this market, including effects of changed prices for inputs and outputs. It takes the perspective of a sector, instead of a single firm.

It is quite complicated to work out the assumptions and key characteristics of Partial Equilibrium Models. There are numerous Partial Equilibrium Models, and their structure is chosen to mimic the market of interest. Still, there are two assumptions that are typical for Partial Equilibrium Models. The first assumption concerns the markets for other products. It is assumed that the prices of all other products outside of the model remain constant and that their markets are in equilibrium. Essentially, potential effects on other markets are neglected. Consider a hypothetical model of the market for illuminants to assess the effects of a ban of incandescent light bulbs. In this model, it is assumed that the prices for lamps themselves, which serve as complements for light bulbs, remain unchanged. The same holds true for other sources of light, like candles, that can serve as substitutes. The second assumption covers income effects. It is assumed that the consumer's income level does not change due to the policy measure. The ban of the light bulbs may reduce the costs of lighting over the life cycle, increasing people's income in real terms. This may also contribute to a rebound effect. Such income effects are assumed non-existent as well.

A topic that may serve as an example for the usefulness of Partial Equilibrium Models is the promotion of bio fuels. ${ }^{8}$ Fuels gained from renewable sources are seen as an environmentally sound substitute for fossil fuels, reducing the emissions of greenhouse gases and the depletion of non-renewable resources alike. When analysing bio fuels from a life cycle perspective, it becomes clear that farming the biomass, processing it into fuels and delivering the final product to the customer needs fossil fuels as inputs, which partly offsets the gains (see e.g. von Blottnitz and Curran, 2007 for an overview over recent studies).

Besides these environmental effects, other impacts of the promotion of bio fuels are induced by economic mechanisms. These mechanisms are sketched here briefly to demonstrate the usefulness of Partial Equilibrium Models. First notice that biomass for bio fuel production,

\footnotetext{
${ }^{8}$ Thanks to Gjalt Huppes for suggesting this topic as an example.
} 
especially for those of the first generation, are substitutes to biomass for food production. The policy intervention now increases the demand for bio fuels and thereby the demand for biomass. This has important implications for land use. From a farmer's point of view, the rising demand makes production for bio fuels more profitable. It is possible to employ land which is already being used for agricultural purposes to produce bio fuel instead of food. The second option is to convert non-agricultural areas into cropland, which again has environmental implications for both net greenhouse gas emissions and for biodiversity. An increase in production of biomass for fuel production crowds out food production and increases the costs of inputs, both leading to increasing food prices. Especially the impact of bio fuel demand on the drastic increase in food prices between 2003 and 2008 is subject to a heated debate (e.g. Mitchell, 2008; Headey and Fan, 2008). For actual decision making, it is important to answer the questions of price effects, increased land use or the efficiency of policy instruments in a quantitative manner. A Partial Equilibrium Model of agricultural markets can be used to answer these questions (OECD, 2008). It should be emphasised, that a boundary setting problem arises here. It is crucial that the model covers food as well as biomass production, in order to the trade-off to become visible. Additionally, the assumption that prices in other markets stay unchanged and that income effects are negligible, is questionable. Especially when questions about economic growth or income distribution are addressed, a general equilibrium framework seems more appropriate (Arndt et al., 2010).

Partial Equilibrium Models focus on one industry and assume the rest of the economy to be constant. This enables the model to concentrate on the market of interest. This market can be modelled in detail and therefore we can draw conclusions in a much more precise manner than with more general models of the whole economy. Still, the approach only gives reliable results, when the underlying assumptions hold. Generally, one can presume that prices outside of the model remain constant and income effects are negligible, if policy intervention is concentrated on a single industry and small in magnitude.

We have described the circumstances under which a Partial Equilibrium Model is appropriate. Now, they are to be combined with life cycle modelling. There are two approaches to archive this goal. We could either hard link both models into one combined model or use two distinct models that are soft linked by an exchange of data. A notable example of the latter approach is Bouman et al. (2000), who discuss a comparison of conventional lead batteries and lead free "green" batteries. They carried out the comparison by using a Substance Flow Analysis (SFA), a Life Cycle Assessment and Partial Equilibrium Model in an iterative manner. All 
three models are applied to reduce material depletion, emissions and waste disposal, discussing potential measures to reach these goals.

A soft linking approach allows the researcher to avoid an increase in complexity of a single model that would contain the characteristics of all three models. The stepwise approach also makes interpretation and critique of every single step possible. From a practical point of view, the use of already existing models is advantageous, as it reduces costs and effort in the analysis. A hard link model would allow for a consistent framework, with corresponding boundaries. Still, Life Cycle Assessment and economic Partial Equilibrium Models come up with very different characteristics, making an integrated approach complex. Soft linking therefore seems to be the more promising.

\subsection{Linking Life Cycle Assessment to General Equilibrium Models}

While Partial Equilibrium Models only analyse one certain market within an economy, General Equilibrium Models represent the economy as a whole. They are theoretically based on the work of Arrow and Debreu (1954), who prove that under certain assumptions there is a competitive equilibrium in an economy. While theoretical models of a whole economy can be used to draw conclusions about policy intervention in a comparative-static manner, they need to be extremely stylised to keep them analytically traceable.

Numerical models are called for, if real world policy measures are to be evaluated. Such models, which are rooted in the Arrow/Debreu framework and which are constructed on a sufficient level of detail are called Computable General Equilibrium (CGE) or Applied General Equilibrium (AGE) Models. Since the seminal work of Johansen (1960), Computable General Equilibrium Models have developed rapidly and have gained importance in policy making (Devarajan and Robinson, 2005). One major area of application is Environmental Economics (for an overview see e.g. Conrad, 2002; Böhringer and Löschel, 2006).

To grasp the spirit of CGE Models, key assumptions underlying a basic CGE Model are outlined below. A more detailed description is provided by Shoven and Whalley (1992), Böhringer et al. (2003) and Sue Wing (2004). The model is based on neo-classical microeconomic theory. The economy consists of several industries, each producing one good. Each industry is typified by one representative firm that maximises its profits. The households are modelled as one representative household that maximises its utility. Usually, the production functions in the model are of a Constant Elasticity of Substitution (CES) type, and 
so is the utility function. The whole economy exhibits constant elasticites of scale, meaning that an increase by 10 percent in all input factors yields an increase of output by 10 percent. All markets are assumed to be competitive. Most CGE models are static, so investment and savings decisions are exogenous.

To be in equilibrium, the model has to fulfil three conditions. The first one is market clearance. All goods produced are demanded and all production factors are employed by the firms. The second condition is the zero profit condition. Firms spend all their revenue on intermediate inputs and production factors. The last condition is that the household income balance has to hold. The representative consumer spends all his factor income on goods (Sue Wing, 2004).

After discussing the main assumptions, data underlying CGE Models remains to be explained. The methods to feed numbers into the model are described exemplarily for a CES production function. Within these production functions an endogenous substitution between inputs is possible. A production function of this type with two inputs, Labour and Capital, is presented in equation (4)

$$
y=\gamma\left(\alpha \cdot L^{\rho}+(1-\alpha) K^{\rho}\right)^{1 / \rho} \text {, with } \rho=\frac{\sigma-1}{\sigma} .
$$

In this equation, $y$ denotes the output of the representative firm and $L$ and $K$ the labour and capital inputs, respectively. $\gamma$ is a scaling parameter and $\rho$ the substitution parameter, which is determined by the elasticity of substitution between the input factors $\sigma$. The variable $\alpha$ is the share parameter in the production function, it determines the shares of labour and capital used to produce the output $y$.

The elasticites are typically either taken from the economic literature or set to values that appear reasonable to the modeller. The scale and share parameters remain to be determined. This is usually done by calibrating the model to a base year dataset (for an overview see Dawkins et al., 2001). The source of data for this process is Social Accounting Matrices (SAM). ${ }^{9}$ An SAM is an economy wide accounting system in matrix form, based on the principle of double bookkeeping. It is similar to Input-Output tables, but extends them by displaying the links between factor income and demand for goods explicitly (Robinson, 2006). When calibrating the model, the scale and share parameters are set in a way that they

\footnotetext{
${ }^{9}$ For an introduction into Social Accounting Matrices, see King (1985).
} 
reproduce the base year. Then, the model is set up numerically and can be used to simulate the effects of policy intervention.

Computable General Equilibrium Models enable the researcher to analyse the whole economy on a disaggregated level, building upon a coherent microeconomic theoretical foundation. Using the theoretical framework, ex ante assessments of policy intervention are possible. Scenarios can be defined, computed and compared to a "no policy" base case. Due to the model covering the whole economy, general equilibrium effects as those discussed in chapter 3 can be included. Furthermore, when assessing impacts on sustainability, CGE models can incorporate environmental, economic and social aspects simultaneously (Böhringer and Löschel, 2006). ${ }^{10}$

The critique of CGE Models is concerned mainly with three arguments. The first one is the black box problem (Böhringer, et al., 2003). Due to the computational complexity and the comprehensiveness of the model, it is hard to capture mechanisms that produce the outcome intuitively. Therefore, the results need to be accompanied by a comprehensible discussion of the model. The second argument focuses on the calibration approach. Calibration determines the parameters of interest. It is based on one observation and rules out the possibility to statistically test the model. It is also possible that biases occurring in the base year are introduced into the parameters (for a discussion see Dawkins, et al., 2001). The third argument deals with the strong assumptions of the model. It ranges from the problem of too strict function forms (McKitrick, 1998) to a complete refusal of the model (Ackerman, 2002). With regards to this argument, one has to keep in mind that it is not developed as an exact representation of reality. Instead, it must be able to yield results sufficiently close enough to reality to be of relevance. CGE models can archive this (Kehoe et al., 1995).

If large scale regulatory measures are to be assessed, where the key assumptions of Partial Equilibrium Models do not hold any more, CGE Models are promising. The question is how they can be linked with LCA. The use of CGE models in Industrial Ecology has been discussed before (Ekvall, 2002; Lave, et al., 1995), but also rejected for computational reasons (Lave, et al., 1995). The actual introduction of CGE modelling into the field of Industrial Ecology remains scarce (Ibenholt, 2002).

A notable example can be found in Kandelaars (1999). There, a CGE model is linked to a model of physical flows and applied to compare several forms of levies on zinc and lead. 
Another application of CGE Modelling can be found in Kløverpris et al. (2008, 2010). There, the authors modify the Global Trade Analysis Project (GTAP) CGE Model to calculate the effects on land use triggered by an increase in demand for agricultural goods. The approach was chosen to allow for a more realistic modelling of land use in the Inventory Analysis phase for LCAs dealing with agricultural goods.

A promising way to unite Life Cycle Thinking and economic modelling is a Life Cycle Based CGE (LCB-CGE) Model. Several extensions are needed in order to be able to analyse product based regulation, compared to the basic CGE model outlined before. First of all, it is necessary to make functional units the object of observation, instead of goods, at least for the product of interest. A comparable approach has been chosen by Huppes et al. (2006). It is advantageous here, that the whole production side is covered by the model, similar to an Input-Output model. Boundary setting problems are avoided, it is just necessary to connect the products that belong to a functional unit.

The functional unit will most certainly include durable goods. These goods are not consumed once and then are "gone”, but they are used over a longer time span and disposed afterwards. The length of the life cycle of these goods may depend on the regulatory measure. Therefore, it becomes necessary to dynamise the model to make replacement decisions endogenous. Also, a way to determine which goods produced belong to a functional unit is needed. The information gathered in Life Cycle Inventory Analyses can serve as an input here ${ }^{11}$, but they need to be projected on an economy-wide level. Sometimes it is the case, that a product of interest is composed in a sector with other very different products. Then it becomes necessary to disaggregate the sector to reach appropriate results.

\section{Conclusions}

Industrial Ecology in general and Life Cycle Assessment in particular gain increasing importance in policy making. This paper seeks to clarify the role of Industrial Ecology tools to this objective. Three questions were asked regarding this. They remain to be answered.

The first question is: Are LCA and MFA appropriate tools for policy making? They would be, if they were able to consider the economic effects induced by regulatory action. These include benefits and costs within the whole economy, rebound effects and distributive consequences. MFA is a highly aggregated macro tool, measuring everything in weight. Economy is

\footnotetext{
${ }^{10}$ In practice, most CGE Models focus on economic aspects and, to a lesser degree, on ecological questions.
} 
perceived as a black box. Due to these characteristics, economy-wide MFA can not guide policy makers appropriately. LCA analyses the environmental impacts of products from cradle to grave. It can capture the benefits of regulation and, with reasonable modification, direct costs of regulation as well. As an instrument on micro level, it has difficulties with effects that occur in a partial or general equilibrium framework. Therefore, LCA is a promising approach to tackle environmental problems, but it can not guide policy makers as a standalone tool.

This leads to the second question: Which economic model is advisable for policy evaluation, depending on the regulation to be assessed? When looking at measures that are small in magnitude and concentrated on a specific industry, a Partial Equilibrium Model that mimics this industry is appropriate. In other cases, the multifarious general equilibrium effects call for adequate modelling framework. Computable General Equilibrium Models provide such a framework for ex ante policy evaluation.

The last question is: What could a combination between quantitative economic models, in particular Computable General Equilibrium Models, and LCA look like? For a combination with Partial Equilibrium Models, a soft link between LCA and an, maybe already existing, Economic Model seems most promising. For CGE Models, it appears preferable to develop a consistent Life Cycle Based CGE Model. It needs to be based on functional units rather than on goods for the product to be assessed. LCA can serve as an input to construct the life cycle correctly. The model should also capture the fact that life cycles usually are the life cycles of durable goods, inducing the need for a dynamised CGE model.

There are several directions of further research needed in the future. First of all, it is intended by this paper to stimulate the discussion about the role of economic thought and economic modelling in Industrial Ecology. This holds especially true, when the tools are intended to be used in policy making. When looking in the other direction, Industrial Ecology can also inspire the work of environmental economists. The most obvious need for research, however, is the actual development of a LCB-CGE model. The model recommended in this paper from a theoretical point of view has to be constructed and applied. Then, the idea behind this paper can prove itself to reality.

\footnotetext{
${ }^{11}$ This approach was indicated before by Ekvall (2002).
} 


\section{References}

Ackerman, F. (2002), Still dead after all these years: interpreting the failure of general equilibrium theory, Journal of Economic Methodology 9 (2), 119-139.

Adriaanse, A., S. Bringezu, A. Hammond, Y. Moriguchi, E. Rodenburg, D. Rogich, and H. Schütz (1997). Resource flows: The material basis of industrial economies, Washington, D.C.

Allenby, B. R., and W. E. Cooper (1994), Understanding industrial ecology from a biological systems perspective, Total Quality Environmental Management 3 (3), 343-354.

Andersson, K., T. Ohlsson, and P. Olsson (1998), Screening life cycle assessment (LCA) of tomato ketchup: a case study, Journal of Cleaner Production 6 (3-4), 277-288.

Andrews, C. J. (2000), Building a Micro Foundation for Industrial Ecology, Journal of Industrial Ecology 4 (3).

Arndt, C., R. Benfica, F. Tarp, J. Thurlow, and R. Uaiene (2010), Biofuels, Poverty, and Growth: A Computable General Equilibrium Analysis of Mozambique, Environment and Development Economics 15 (1), 81-105.

Arrow, K. J., and G. Debreu (1954), Existence of an Equilibrium for a Competitive Economy, Econometrica 22 (3), 265-290.

Ayres, R. U. (1994), Industrial metabolism: Theory and policy, in: Ayres, R. U., and U. E. Simonis, (Eds.), Industrial Metabolism: Restructuring for Sustainable Development, Tokyo et al., 3-20.

Bauer, D. (2009), Environmental Policy. A Growing Opportunity for Material Flow Analysis, Journal of Industrial Ecology 13 (5), 666-669.

Böhringer, C., and A. Löschel (2006), Computable general equilibrium models for sustainability impact assessment: Status quo and prospects, Ecological Economics 60 (1), 49-64.

Böhringer, C., T. F. Rutherford, and W. Wiegard (2003), Computable General Equilibrium Analysis: Opening a Black Box, ZEW Discussion Paper No. 03-56.

Bouman, M., R. Heijungs, E. van der Voeta, J. C. J. M. van den Bergh, and G. Huppes (2000), Material flows and economic models: an analytical comparison of SFA, LCA and partial equilibrium models, Ecological Economics 32 (2), 195-216.

Bringezu, S., H. Schütz, and S. Moll (2003), Rationale for and Interpretation of EconomyWide Materials Flow Analysis and Derived Indicators, Journal of Industrial Ecology 7 (2), 43-64.

Bringezu, S., H. Schütz, S. Steger, and J. Baudisch (2004), International comparison of resource use and its relation to economic growth: The development of total material requirement, direct material inputs and hidden flows and the structure of TMR, Ecological Economics 51 (1-2), 97-124. 
Cederberg, C., and B. Mattsson (2000), Life cycle assessment of milk production - a comparison of conventional and organic farming Journal of Cleaner Production 8 (1), 49-60.

Cleveland, C. J., and M. Ruth (1998), Indicators of Dematerialization and the Materials Intensity of Use, Journal of Industrial Ecology 2 (3), 15-49.

Coase, R. H. (1960), The Problem of Social Cost, Journal of Law and Economics 3 (1), 1-44.

Conrad, K. (2002), Computable General Equilibrium Models in Environmental and Resource Economics, in: Tietenberg, T., and H. Folmer, (Eds.), The International Yearbook of Environmental and Resource Economics, 2002/03, Cheltenham, 66-114.

Cordella, M., A. Tugnoli, G. Spadoni, F. Santarelli, and T. Zangrando (2008), LCA of an Italian Lager Beer International Journal of Life Cycle Assessment 13 (2), 133-139.

Daniels, P. L. (2002), Approaches for Quantifying the Metabolism of Physical Economies. A Comparative Survey. Part II: Review of Individual Approaches, Journal of Industrial Ecology 6 (1), 65-88.

Daniels, P. L., and S. Moore (2001), Approaches for Quantifying the Metabolism of Physical Economies. Part I: Methodological Overview, Journal of Industrial Ecology 5 (4), 6993.

Dawkins, C., T. N. Srinivasan, and J. Whalley (2001), Calibration, in: Heckman, J. J., and E. E. Leamer, (Eds.), Handbook of Econometrics. Volume 5, North Holland, 3653-3703.

Devarajan, S., and S. Robinson (2005), The Influence of Computable General Equilibrium Model on Policy, in: Kehoe, T. J., T. N. Srinivasan, and J. Whalley, (Eds.), Frontiers in Applied General Equilibrium Modeling: In Honor of Herbert Scarf.

Ekvall, T. (2002), Cleaner production tools: LCA and beyond, Journal of Cleaner Production 10 (5), 403-406.

Erkman, S. (1997), Industrial ecology: An historical view, Journal of Cleaner Production 5 (1-2), 1-10.

European Commission (2003). Integrated Product Policy. Building on Environmental LifeCycle Thinking (COM(2003) 302).

European Commission (2005). Directive 2005/32/EC.

Eurostat (2001). Economy-wide material flow accounts and derived indicators. A methodological guide, Luxemburg.

Finnveden, G. (1997), Valuation methods within LCA - Where are the values? , International Journal of Life Cycle Assessment 2 (3), 163-169.

Finnveden, G. (1999), A Critical Review of Operational Valuation/Weighting Methods for Life Cycle Assessment, AFR-Report No. 253. 
Finnveden, G., M. Z. Hauschild, T. Ekvall, J. B. Guinée, R. Heijungs, S. Hellweg, A. Koehler, D. Pennington, and S. Suh (2009), Recent developments in Life Cycle Assessment, Journal of Environmental Management 91 (1), 1-21.

Fischer-Kowalski, M. (1998), Society's Metabolism : The Intellectual History of Materials Flow Analysis, Part I, 1860- 1970 Journal of Industrial Ecology 2 (1), 61-78.

Fischer-Kowalski, M., and W. Hüttler (1998), Society's Metabolism : The Intellectual History of Materials Flow Analysis, Part II, 1970-1998, Journal of Industrial Ecology 2 (4), 107-136.

Friedman, A. M. (2003). The Measurements of Environmental and Resource Values, Washington, D.C.

Frosch, R. A., and N. E. Gallopoulos (1989), Strategies for Manufacturing, Scientific American 189 (3), 144-152.

Giljum, S., and K. Hubacek (2009), Conceptual Foundations and Applications of Physical Input-Output Tables, in: Suh, S., (Ed.), Handbook of Input-Output Economics in Industrial Ecology, Dordrecht, 61-75.

Goulder, L. H. (1995), Environmental Taxation and the Double Dividend: A Reader's Guide, International Tax and Public Finance 2 (2), 157-183.

Greening, L. A., D. L. Greene, and C. Difiglio (2000), Energy efficiency and consumption the rebound effect — a survey, Energy Policy 28 (6-7), 389-401.

Guinée, J. B. (2002). Handbook on Life Cycle Assessment. Operational Guide to the ISO Standards, Dorndrecht et al.

Haab, T. C., and K. E. McConnell (2002). Valuing Environmental And Natural Resources. The Econometrics of Non-market Valuation, Cheltenham et al.

Hanley, N., P. G. McGregor, J. K. Swales, and K. Turner (2009), Do increases in energy efficiency improve environmental quality and sustainability?, Ecological Economics 68 (3), 692-709.

Hazilla, M., and R. J. Kopp (1990), Social Cost of Environmental Quality Regulations: A General Equilibrium Analysis, Journal of Political Economy 98 (4), 853-873.

Headey, D., and S. Fan (2008), Anatomy of a crisis: the causes and consequences of surging food prices, Agricultural Economics 39 (S1), 375-391.

Heijungs, R., A. de Koning, S. Suh, and G. Huppes (2006), Toward an Information Tool for Integrated Product Policy: Requirements for Data and Computation, Journal of Industrial Ecology 10 (3), 147-158.

Heiskanen, E. (2002), The institutional logic of life cycle thinking, Journal of Cleaner Production 10 (5), 427-437. 
Hendrickson, C. T., A. Horvath, S. Joshi, and L. B. Lave (1998), Economic Input-Output Models for Environmental Life-Cycle Assessment Environmental Science \& Technology 32 (7), 184A-191A.

Hendrickson, C. T., L. B. Lave, and H. S. Matthews (2006). Environmental Life Cycle Assessment of Goods and Services. An Input-Output Approach, Washington, DC.

Hertwich, E. G., W. S. Pease, and C. P. Koshland (1997), Evaluating the environmental impact of products and production processes: a comparison of six methods, Science of the Total Environment 196 (1), 13-29.

Hochschorner, E., J. Hägvall, G. Finnveden, E. Griffing, and M. Overcash (2006), Environmental life cycle assessment of a pre-fragmented high explosive grenade, Journal of Chemical Technology \& Biotechnology 81 (3), 461-475.

Hunkeler, D., K. Lichtenvort, and G. Rebitzer (2008). Environmental Life Cycle Costing, Pensacola, FL.

Hunt, R. G., and W. E. Franklin (1996), LCA - How it came about - Personal reflections on the origin and the development of LCA in the USA, The International Journal of Life Cycle Assessment 1 (1), 4-7.

Huppes, G., A. de Koning, S. Suh, R. Heijungs, L. van Oers, P. H. Nielsen, and J. B. Guinée (2006), Environmental Impacts of Consumption in the European Union. HighResolution Input-Output Tables with Detailed Environmental Extensions, Journal of Industrial Ecology 10 (3), 129-146.

Ibenholt, K. (2002), Materials flow analysis and economic modelling, in: Ayres, R. U., and L. W. Ayres, (Eds.), Handbook of Industrial Ecology, Cheltenham.

Jaffe, A. B., S. R. Peterson, P. R. Portney, and R. N. Stavins (1995), Environmental Regulation and the Competitiveness of U.S. Manufacturing: What Does the Evidence Tell Us?, Journal of Economic Literature 33 (1), 132-163.

Jalas, M. (2002), A time use perspective on the materials intensity of consumption Ecological Economics 41 (1), 109-123.

Johansen, L. (1960). A multi-sectoral study of economic growth, Amsterdam.

Jørgensen, A., A. Le Bocq, L. Nazarkina, and M. Z. Hauschild (2008), Methodologies for social life cycle assessment International Journal of Life Cycle Assessment 13 (2), 96103.

Jorgenson, D. W., and P. J. Wilcoxen (1990), Environmental Regulation and U.S. Economic Growth, RAND Journal of Economics 21 (2), 314-340.

Joshi, S. (1999), Product Environmental Life-Cycle Assessment Using Input-Output Techniques, Journal of Industrial Ecology 3 (2-3), 95-120.

Kandelaars, P. (1999). Economic Models of Material-Product Chains for Environmental Policy Analysis, Bosten, MA. 
Kehoe, T. J., C. Polo, and F. Sancho (1995), An evaluation of the performance of an applied general equilibrium model of the Spanish economy, Economic Theory 6 (1), 115-141.

Khazzoom, J. D. (1980), Economic Implications of Mandated Efficiency in Standards for Household Appliances, Energy Journal 1 (4), 21-40.

King, B. B. (1985), What is a SAM? A Layman's Guide to Social Accounting Matrices, World Bank Staff Working Paper No. 463.

Kløverpris, J., H. Wenzel, and P. H. Nielsen (2008), Life cycle inventory modelling of land use induced by crop consumption. Part 1: Conceptual analysis and methodological proposal, International Journal of Life Cycle Assessment 13 (1), 13-21.

Kløverpris, J. H., K. Baltzer, and P. H. Nielsen (2010), Life cycle inventory modelling of land use induced by crop consumption. Part 2: Example of wheat consumption in Brazil, China, Denmark and the USA, International Journal of Life Cycle Assessment 15 (1), 90-103.

Kooreman, P. (1996), Individual Discounting, Energy Conservation, and Household Demand for Lighting, Resource and Energy Economics 18 (1), 103-114.

Lave, L. B., E. Cobas-Flores, C. T. Hendrickson, and F. C. McMichael (1995), Using InputOutput Analysis to Estimate Economy-wide Discharges, Environmental Science \& Technology 29 (9), 420A-426A.

Leontief, W. W. (1936), Quantitative Input and Output Relations in the Economic Systems of the United States, Review of Economics and Statistics 18 (3), 105-125.

Leontief, W. W. (1970), Environmental Repercussions and the Economic Structure: An InputOutput Approach, Review of Economics and Statistics 52 (3), 262-271.

Lifset, R., and T. E. Graedel (2002), Industrial ecology: goals and definitions, in: Ayres, R. U., and L. Ayres, (Eds.), A Handbook of Industrial Ecology.

Lopes, E., A. Dias, L. Arroja, I. Capela, and F. Pereira (2003), Application of life cycle assessment to the Portuguese pulp and paper industry, Journal of Cleaner Production 11 (1), 51-59.

Matthews, E., C. Amann, S. Bringezu, M. Fischer-Kowalski, W. Hüttler, R. Kleijn, Y. Moriguchi, C. Ottke, E. Rodenburg, D. Rogich, H. Schandl, H. Schütz, E. van der Voet, and H. Weisz (2000). The weight of nations: Material outflows from industrial economies, Washington, D.C.

McKitrick, R. R. (1998), The econometric critique of computable general equilibrium modeling: the role of functional forms, Economic Modelling 15 (4), 543-573.

Miller, R. E., and P. D. Blair (2009). Input-Output analysis: foundations and extensions, Cambridge et al. 
Mitchell, D. (2008), A Note on Rising Food Prices, World Bank Policy Research Working Paper No. 4682.

Morgenstern, R. D., W. A. Pizer, and J.-S. Shih (2002), Jobs Versus the Environment: An Industry-Level Perspective, Journal of Environmental Economics and Management 43 (3), 412-436.

Norris, G. A. (2001a), Integrating Economic Analysis into LCA, Environmental Quality Management 10 (3), 59-64.

Norris, G. A. (2001b), Integrating life cycle cost analysis and LCA International Journal of Life Cycle Assessment 6 (2), 118-120.

Notarnicola, B., G. Huppes, and N. W. van den Berg (1998), Evaluating options in LCA: The emergence of conflicting paradigms for impact assessment and evaluation, International Journal of Life Cycle Assessment 3 (5), 289-300.

OECD (2008). Biofuel Support Policies: An Economic Assessment, Paris.

Owens, J. W. (1997), Life-Cycle Assessment: Constraints on Moving from Inventory to Impact Assessment, Journal of Industrial Ecology 1 (1), 37-49.

Parry, I. W. H., H. Sigman, M. Walls, and R. C. Williams (2005), The Incidence of Pollution Control Policies, Resources for the Future Discussion Paper No. 05-24.

Pennington, D., G. Potting, G. Finnveden, O. Lindeijer, O. Jolliet, T. Rydberg, and G. Rebitzer (2004), Life cycle assessment Part 2: Current impact assessment practice Environment International 30 (5), 721-739.

Pizer, W. A., and R. Kopp (2005), Calculating the Costs of Environmental Regulation, in: Mäler, K.-G., and J. R. Vincent, (Eds.), Handbook of Environmental Economics, 3, 1307-1351.

Rebitzer, G., T. Ekvall, R. Frischknecht, D. Hunkeler, G. A. Norris, T. Rydberg, W.-P. Schmidt, S. Suh, B. P. Weidema, and D. Pennington (2004), Life cycle assessment: Part 1: Framework, goal and scope definition, inventory analysis, and applications, Environment International 30 (5), 701-720.

Robinson, S. (2006), Macro Models and Multipliers: Leontief, Stone, Keynes, and CGE Models in: de Janvry, A., and R. Kanbur, (Eds.), Poverty, Inequality and Development. Essays in Honor of Erik Thorbecke, 205-232.

Schmalensee, R. (1993), The Costs of Environmental Protection, MIT Center for Energy and Environmental Policy Research No. 93-015WP.

Schwab Castella, P., I. Blanc, M. Gomez Ferrer, B. Ecabert, M. Wakeman, J.-A. Manson, D. Emery, S.-H. Han, J. Hong, and O. Jolliet (2009), Integrating life cycle costs and environmental impacts of composite rail car-bodies for a Korean train, International Journal of Life Cycle Assessment 14 (5), 429-442.

Shoven, J. B., and J. Whalley (1992). Applying General Equilibrium. 
Sorrell, S., and J. Dimitropoulos (2007). The Rebound Effect. An assessment of the evidence for economy-wide energy savings from improved energy efficiency, London.

Sorrell, S., J. Dimitropoulos, and M. Sommerville (2009), Empirical estimates of the direct rebound effect: A review Energy Policy 37 (4), 1356-1371.

Spielmann, M., P. de Haan, and R. W. Scholz (2008), Environmental rebound effects of highspeed transport technologies: a case study of climate change rebound effects of a future underground maglev train system, Journal of Cleaner Production 16 (13), 1388-1398.

Stoppato, A. (2008), Life cycle assessment of photovoltaic electricity generation, Energy 33 (2), 224-232.

Sue Wing, I. (2004), Computable General Equilibrium Models and Their Use in EconomyWide Policy Analysis: Everything you Ever Wanted to Know (but were afraid to ask), MIT Joint Program on the Science and Policy of Global Change. Technical Note No. 6.

Suh, S., M. Lenzen, G. J. Treloar, H. Hondo, A. Horvath, G. Huppes, O. Jolliet, U. Klann, W. Krewitt, Y. Moriguchi, J. Munksgaard, and G. A. Norris (2004), System Boundary Selection in Life-Cycle Inventories Using Hybrid Approaches, Environmental Science \& Technology 38 (3), 657-664.

Thiesen, J., T. S. Christensen, T. G. Kristensen, R. D. Andersen, B. Brunoe, T. K. Gregersen, M. Thrane, and B. P. Weidema (2008), Rebound effects of price differences, International Journal of Life Cycle Assessment 13 (2), 104-114.

Udo de Haes, H. A., R. Heijungs, S. Suh, and G. Huppes (2004), Three Strategies to Overcome the Limitations of Life-Cycle Assessment, Journal of Industrial Ecology 8 (3), 19-32.

Vercalsteren, A., C. Spirinckx, and T. Geerken (2010), Life cycle assessment and ecoefficiency analysis of drinking cups used at public events, International Journal of Life Cycle Assessment 15 (2), 221-230.

von Blottnitz, H., and M. A. Curran (2007), A review of assessments conducted on bioethanol as a transportation fuel from a net energy, greenhouse gas, and environmental life cycle perspective, Journal of Cleaner Production 15 (7). 